\title{
Tlx1/3 and Ptf1a Control the Expression of Distinct Sets of Transmitter and Peptide Receptor Genes in the Developing Dorsal Spinal Cord
}

\author{
Zhen Guo, ${ }^{1}$ Congling Zhao, ${ }^{2}$ Menggui Huang, ${ }^{2}$ Tianwen Huang, ${ }^{2}$ Mingran Fan, ${ }^{2}$ Zhiqin Xie, ${ }^{1}$ Ying Chen, ${ }^{1}$ Xiaolin Zhao, ${ }^{2}$ \\ Guannan Xia, ${ }^{1}$ Junlan Geng, ${ }^{2}$ and Leping Cheng ${ }^{2}$ \\ IInstitute of Biochemistry and Cell Biology, and 2Institute of Neuroscience and State Key Laboratory of Neuroscience, Shanghai Institutes for Biological \\ Sciences, Chinese Academy of Sciences, Shanghai 200031, China
}

\begin{abstract}
Establishing the pattern of expression of transmitters and peptides as well as their receptors in different neuronal types is crucial for understanding the circuitry in various regions of the brain. Previous studies have demonstrated that the transmitter and peptide phenotypes in mouse dorsal spinal cord neurons are determined by the transcription factors Tlx1/3 and Ptfla. Here we show that these transcription factors also determine the expression of two distinct sets of transmitter and peptide receptor genes in this region. We have screened the expression of 78 receptor genes in the spinal dorsal horn by in situ hybridization. We found that receptor genes Gabral, Gabra5, Gabrb2, Gria3, Grin3a, Grin3b, Galr1, and Npy1r were preferentially expressed in Tlx3-expressing glutamatergic neurons and their derivatives, and deletion of $T l x 1$ and $T l x 3$ resulted in the loss of expression of these receptor genes. Furthermore, we obtained genetic evidence that $T l x 3$ uses distinct pathways to control the expression of receptor genes. We also found that receptor genes Grm3, Grm4, Grm5, Grik1, Grik2, Grik3, and Sstr2 were mainly expressed in Pax2-expressing GABAergic neurons in the spinal dorsal horn, and their expression in this region was abolished or markedly reduced in Ptfla and Pax2 deletion mutant mice. Together, our studies indicate that $T l x 1 / 3$ and Ptfla, the key transcription factors for fate determination of glutamatergic and GABAergic neurons in the dorsal spinal cord, are also responsible for controlling the expression of two distinct sets of transmitter and peptide receptor genes.
\end{abstract}

\section{Introduction}

The dorsal horn of the spinal cord is an integrative center that transmits and processes diverse somatosensory information. The neurons in the dorsal spinal cord can be grouped into excitatory and inhibitory neurons that use glutamate and GABA/glycine as their fast transmitters, respectively (Bennett and Balcar, 1999; Todd and Maxwell, 2000; Todd et al., 2003). Diversity of dorsal horn neurons is also indicated by the restricted expression of peptides in distinct subpopulations (Todd and Spike, 1993). The establishment of functional neural circuits in the dorsal spinal cord relies on the coordinated expression of transmitters and peptides as well as their cognate receptors (Graham et al., 2007; Todd, 2010). The molecular mechanism that controls such coor-

Received Dec. 19, 2011; revised April 17, 2012; accepted May 3, 2012.

Author contributions: L.C. designed research; Z.G., C.Z., M.H., T.H., M.F., Z.X., Y.C., X.Z., G.X., and J.G. performed research; Z.G. and L.C. analyzed data; L.C. wrote the paper.

This work was supported by the 973 Program from The Ministry of Science and Technology of China (2011CBA00400), the "Strategic Priority Research Program" of the Chinese Academy of Sciences (XDA01020306), and the 973 Program (2007CB947102). We are grateful to Dr. M.-M. Poo for critical reading of and comments on this manuscript, Drs. S. Shirasawa and S. Korsmeyer for T/x 1 and T/x3 null mice, M. Goulding for $L b \times 1$ and Pax2 mutant mice, C. Wright and the Mutant Mouse Regional Resource Center for Ptf1 $a^{c r e}$ mutant mice, S. Arber for the Tau$n L a c Z$ reporter mice, and Q. Ma for the T/x3-cre mice. We thank J. Ning and Y. Bu for cloning some in situ hybridization probes.

Correspondence should be addressed to Leping Cheng, Institute of Neuroscience and State Key Laboratory of Neuroscience, Shanghai Institutes for Biological Sciences, Chinese Academy of Sciences, 320 Yue Yang Road, Shanghai 200031, China. E-mail: Ipcheng@ion.ac.cn.

DOI:10.1523/JNEUROSCI.6301-11.2012

Copyright $\odot 2012$ the authors $\quad 0270-6474 / 12 / 328509-12 \$ 15.00 / 0$ dinated gene expression among different subpopulations of neurons remains poorly understood.

The past decade has seen much progress in our understanding of the development of dorsal spinal cord neurons (Caspary and Anderson, 2003; Helms and Johnson, 2003; Fitzgerald, 2005; Ma, 2006). A set of transcription factors is known to specify the glutamatergic versus GABAergic cell fates. The basal GABAergic neuronal fate is determined by $L b x l$ (Cheng et al., 2005), whereas the glutamatergic cell fate is determined by $T l \times 1$ and $T l \times 3$, which antagonize $L b x 1$ and are in turn controlled by Gsx1 and Gsx2 (Cheng et al., 2004, 2005; Mizuguchi et al., 2006). Another transcription factor Ptfla acts to suppress Tlx 3 expression and promote GABAergic differentiation (Glasgow et al., 2005; Mizuguchi et al., 2006; Hori et al., 2008). Three studies including ours have also shown that the transcription factors that determine the glutamatergic or GABAergic cell fate also control the expression of distinct sets of peptides in the dorsal horn selectively (Bröhl et al., 2008; Huang et al., 2008; Xu et al., 2008).

In the present study on the expression pattern of transmitter and peptide receptor genes, we have focused on the set of transmitters (glutamate, GABA, and glycine) and peptides that are expressed in the dorsal spinal cord. We have demonstrated that glutamate receptor genes Gria2 and Grik2/3 are expressed preferentially in Pax2-negative excitatory and Pax2-expressing $\left(\mathrm{Pax} 2^{+}\right)$inhibitory neurons in the dorsal horn, respectively, and Gria2 expression is lost and Grik2/3 expression is de-repressed in Tlx1/3 deletion mutant mice (Cheng et al., 2004). Whether 
Table 1. The list of 78 receptor/subunit genes

\begin{tabular}{|c|c|}
\hline Family & Gene name (GenBank accession number) \\
\hline Glutamate & $\begin{array}{l}\text { Gria1 (NM_001113325), Gria2 (NM_001083806), Gria3 (NM_016886), Gria4 (NM_001113180), Grik1 (NM_146072), Grik2 (NM_010349), Grik3 (NM_001081097 } \\
\text { Grik4 (NM_175481), Grik5 (NM_008168), Grin1 (NM_001177657), Grin2a (NM_008170), Grin2b (NM_008171), Grin2c (NM_010350), Grin2d (NM_008172), } \\
\text { Grin3a (NM_001033351), Grin3b (NM_130455), Grm1 (NM_001114333), Grm2 (NM_001160353), Grm3 (NM_181850), Grm4 (NM_001013385), Grm5 } \\
\text { (NM_001081414), Grm6 (NM_173372), Grm7 (NM_177328), Grm8 (NM_008174) }\end{array}$ \\
\hline GABA & $\begin{array}{l}\text { Gabra1 (NM_010250), Gabra2 (NM_008066), Gabra3 (NM_008067), Gabra4 (NM_010251), Gabra5 (NM_176942), Gabra6 (NM_001099641), Gabrb1 } \\
\text { (NM_008069), Gabrb2 (NM_008070), Gabrb3 (NM_008071), Gabrg1 (NM_010252), Gabrg2 (NM_177408), Gabrg3 (NM_008074), Gabrd (NM_008072), Gabre } \\
\text { (NM_017369), Gabrp (NM_146017), Gabrq (NM_020488), Gabrr1 (NM_008075), Gabrr2 (NM_008076), Gabrr3 (NM_001081190), Gabbr1 (NM_019439), Gabbr } \\
\text { (NM_001081141) }\end{array}$ \\
\hline Glycine & Glra1 (NM_020492), Glra2 (NM_183427), Glra3 (NM_080438), Glra4 (NM_010297), Glrb (NM_010298) \\
\hline Peptide & $\begin{array}{l}\text { Galr1 (NM_008082), Galr2 (NM_010254), Galr3 (NM_015738), Sstr1 (NM_009216), Sstr2 (NM_009217), Sstr3 (NM_009218), Sstr4 (NM_009219), Sstr5 } \\
\text { (NM_011425), Npy1r (NM_010934), Npy2r (NM_008731), Ppyr1 (NM_008919), Npy5r (NM_016708), Grpr (NM_008177), Cckar (NM_009827), Cckbr } \\
\text { (NM_007627), Tacr1 (NM_009313), Tacr2 (NM_009314), Tacr3 (NM_021382), Adcyap1r1 (NM_001025372),Vipr1 (NM_011703),Vipr2 (NM_009511), Ntsr1 } \\
\text { (NM_018766), Ntsr2 (NM_008747), Sort1 (NM_019972), Oppr11 (NM_011012), Oprm1 (NM_001039652), Oprd1 (NM_013622), Oprk1 (NM_011011) }\end{array}$ \\
\hline
\end{tabular}

Family represents the ligand for the receptors. Names and GenBank accession numbers of receptor/subunit genes are also shown. A simple font code was used to indicate different expression patterns of these genes in the dorsal horn at $\mathrm{PO}$ : italic for those genes not expressed or very weakly expressed; bold for those genes with lamina enriched expression pattern; and underlining for those genes with scattered expression pattern.

Grik2/3 expression is also controlled by transcription factors that specify the GABAergic cell fate is unknown. Furthermore, whether other transmitter receptor genes in general are controlled by $T l x 1 / 3$ or Ptfla is unknown. Previous studies have also characterized the transcriptional regulation of peptides in glutamatergic and GABAergic neurons (Bröhl et al., 2008; Huang et al., 2008; Xu et al., 2008). In this study, we have further shown that two genes encoding additional peptides, adenylate cyclase activating polypeptide 1 (PACAP/Adcyap1) and neurotensin (NT), are controlled by $T l x 1 / 3$. By screening the expression of 78 receptors/subunits for transmitters and peptides that are known to be expressed in the dorsal spinal cord, we found that $T l \times 1 / 3$ or Ptfla controls the expression of two distinct sets of receptor genes that are associated with glutamatergic and GABAergic neurons.

\section{Materials and Methods}

Animals. The generation of $T l x 1, T l \times 3, L b x 1$, and Pax2 mutant mice, the $T l \times 3^{\text {cre }}$ knock-in mice, and the Tau-nLacZ mice have been described previously (Roberts et al., 1994; Torres et al., 1995; Gross et al., 2000; Shirasawa et al., 2000; Hippenmeyer et al., 2005; Xu et al., 2008). The $P t f 1 a^{\text {cre }}$ mutant mice were obtained from the Mutant Mouse Regional Resource Centers (Kawaguchi et al., 2002). Tlx $3^{\text {cre }}$ knock-in mice were crossed with the Tau-nLacZ mice to fate map the Tlx $3^{+}$neurons. In all timed mating using both male and female mice, the morning that vaginal plugs were observed was considered as E0.5.

In situ hybridization and immunostaining. In situ hybridization experiments were performed following the methods described previously (Huang et al., 2010). Most of the probes were amplified with genespecific sets of PCR primers, and the CDNA templates were prepared from mouse spinal cord and brain at E14.5 or P0.

For double staining that combined in situ hybridization with immunostaining, in situ hybridization was performed first with a lower proteinase K concentration ( $1-2 \mu \mathrm{g} / \mathrm{ml}$ ) and shorter digesting time (3-7 min). After color development with nitro blue tetrazolium/5-bromo-4-chloro3 -indolyl-phosphate as substrates, immunostaining procedures to detect Tlx3, Pax2, or $\beta$-galactosidase proteins were performed. The following first and second antibodies were used: rabbit anti-Pax2 antibody (1:50) (Zymed Laboratories); rabbit anti-Tlx3 antibody (1:400) (Müller et al., 2005; Huang et al., 2010); chicken anti- $\beta$-galactosidase antibody (1:200) (Abcam); goat anti-rabbit Alexa Fluor-488 (1:200) (Invitrogen); and goat anti-chicken Alexa Fluor-488 (1:200) (Invitrogen). To generate the confocal images, the bright-field images of in situ hybridization signals were converted into pseudo-red fluorescent color and then merged with the fluorescent images in Adobe Photoshop (Adobe Systems).

Cell counting. Transverse sections from three pairs of wild-type and mutant embryos were hybridized with the receptor genes. In each section, positive cells with clear nuclear morphology from four to five adjacent dorsal horns were counted, and the values were presented as mean \pm
SD. The differences in values were considered to be significant at $p<0.05$ by Student's $t$ test.

\section{Results}

\section{$T l x 1 / 3$ are required for expression of $P A C A P$ and $N T$}

Before the study of gene expression pattern for transmitter and peptide receptors, we first determined the set of peptides that are expressed in the dorsal spinal cord. Previous studies have characterized the pattern of peptide expression in GABAergic neurons, including neuropeptide Y (NPY), nociceptin/orphanin FQ (N/ OFQ), an early wave of somatostatin (SOM), enkephalin (ENK), dynorphin (DYN), and galanin (GAL) (Bröhl et al., 2008; Huang et al., 2008; Xu et al., 2008). For glutamatergic neurons, transcription factors Gsx1/2, which lie upstream of $T l \times 3$, are known to control the expression of those genes encoding cholecystokinin (CCK), substance P (SP), gastrin-releasing peptide (GRP), and PACAP/Adcyap1 in the dorsal spinal cord (Mizuguchi et al., 2006; Bröhl et al., 2008). Both Tlx1 and Tlx3 are required for the specification of glutamatergic cell fate and the expression of peptide genes encoding CCK, SP, and GRP in dorsal horn (Cheng et al., 2004; Li et al., 2006; Xu et al., 2008). We reasoned that Tlx1/3 may also be required for the expression of PACAP. In situ hybridization demonstrated that this was indeed the case, and PACAP expression was essentially abolished in the dorsal horn of Tlx1/3 deletion mice (data not shown). In addition, because the peptide NT was mainly expressed in glutamatergic neurons in the dorsal spinal cord (Todd et al., 1994), we then examined whether Tlx1/3 are required for its expression. In situ hybridization results revealed that the expression of NT was also compromised in the Tlx1/3 mutant mice (data not shown). Therefore, transcription factors $T l \times 1 / 3$ are required for the coordination of cell fate and the peptide gene expression in glutamatergic neurons in the dorsal spinal cord (Cheng et al., 2004; Li et al., 2006; Xu et al., 2008). This is reminiscent of the fact that transcription factor Ptfla coordinates the cell fate and peptide gene expression in GABAergic neurons in the dorsal spinal cord (Glasgow et al., 2005; Mizuguchi et al., 2006; Bröhl et al., 2008; Huang et al., 2008).

\section{Expression of transmitter and peptide receptor genes in dorsal spinal cord}

Transmitters and peptides known to be expressed in either glutamatergic or GABAergic neurons of the dorsal spinal cord include glutamate, GABA, glycine, CCK, GRP, PACAP, NT, tachykinins (TAKs), SOM, NPY, N/OFQ, ENK, DYN, and GAL (Todd and Spike, 1993; Bennett and Balcar, 1999; Bröhl et al., 


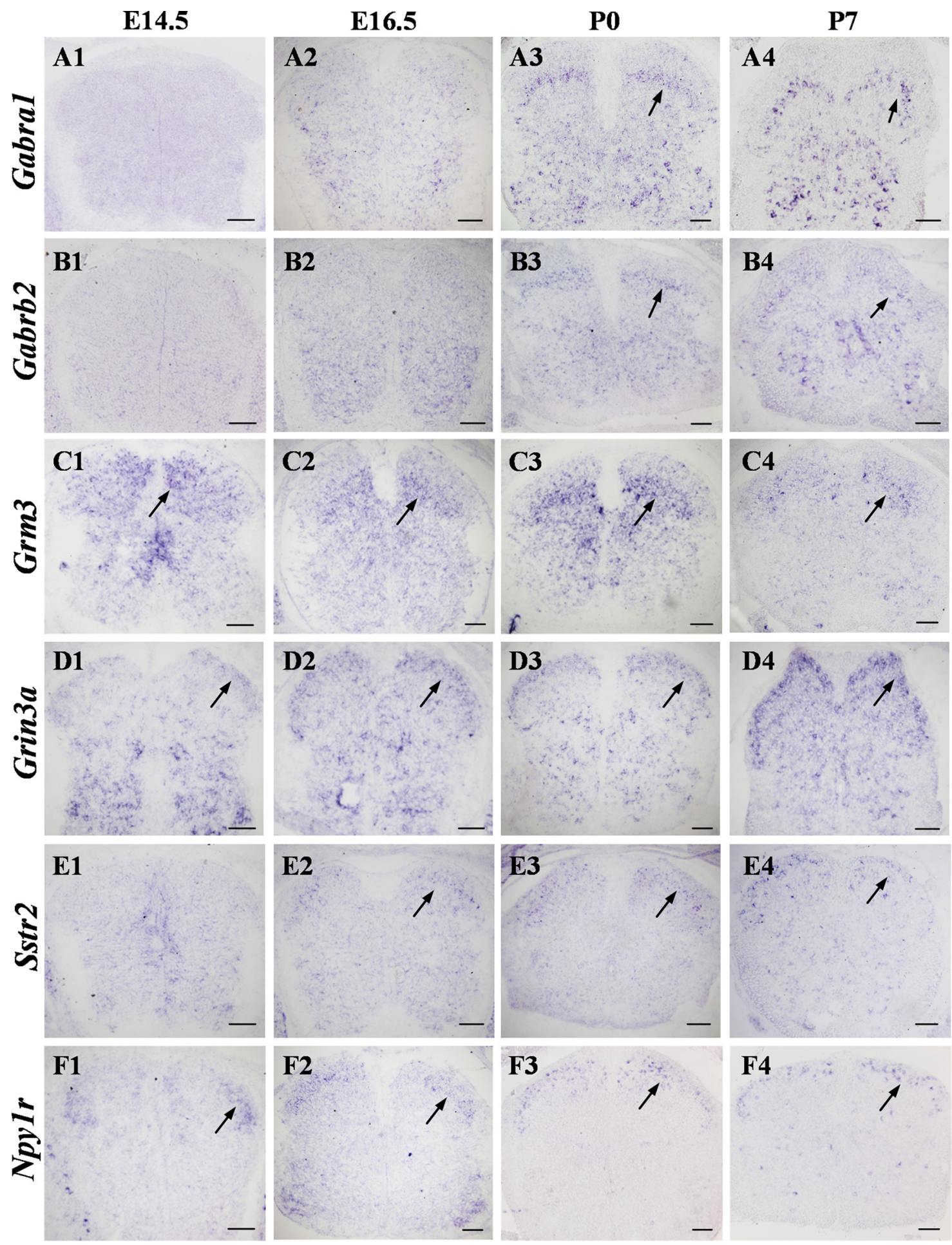

Figure 1. Expression of receptor/subunit genes in the developing spinal cord of mouse. A1-F4, In situ hybridization was performed on sections of mouse spinal cord at different developmental stages (E14.5 to P7) using various receptor/subunit genes as probes. A1-B4, Gabra 1 and Gabrb2 were weakly expressed in the dorsal horn at E16.5. At P0 and P7, the expression of Gabra 1 and Gabrb2 was enriched in laminae II/III of the dorsal horn (A3, A4, B3, B4, arrows). (1-C4, At E14.5, Grm3 was expressed in the dorsal horn (C1, arrow). From E16.5 to P7, Grm3 was enriched in laminae II/III neurons of the dorsal horn (C2-C4, arrows). D1-D4, From E14.5 to P7, Grin3a expression was enriched in the superficial laminae (D1-D4, arrows). E1-E4, From E16.5 to P7, Sstr2 was expressed in superficial laminae neurons (E2-E4, arrows). F1-F4, From E14.5 to P7, Npy1r was expressed in superficial laminae neurons of the dorsal horn (arrows). Scale bars, $100 \mu \mathrm{m}$.

2008; Huang et al., 2008; Xu et al., 2008). We have screened for the expression of 78 receptors or receptor subunits for these transmitters and peptides in the dorsal spinal cord. The list of genes that encode the receptors and receptor subunits is shown in Table 1.

Glutamate receptors can be divided into two distinct classes: ionotropic and metabotropic receptors. Ionotropic receptors in- clude AMPA, kainate, and NMDA receptors (Collingridge et al., 2009; Lodge, 2009). The AMPA receptor family comprises four subunits, GluA1-GluA4, which are encoded by Gria1Gria4, respectively (Nakagawa, 2010). The kainate receptor family comprises five subunits, GluK1-GluK5, which are encoded by Grik1-Grik5 (Contractor et al., 2011). The NMDA 


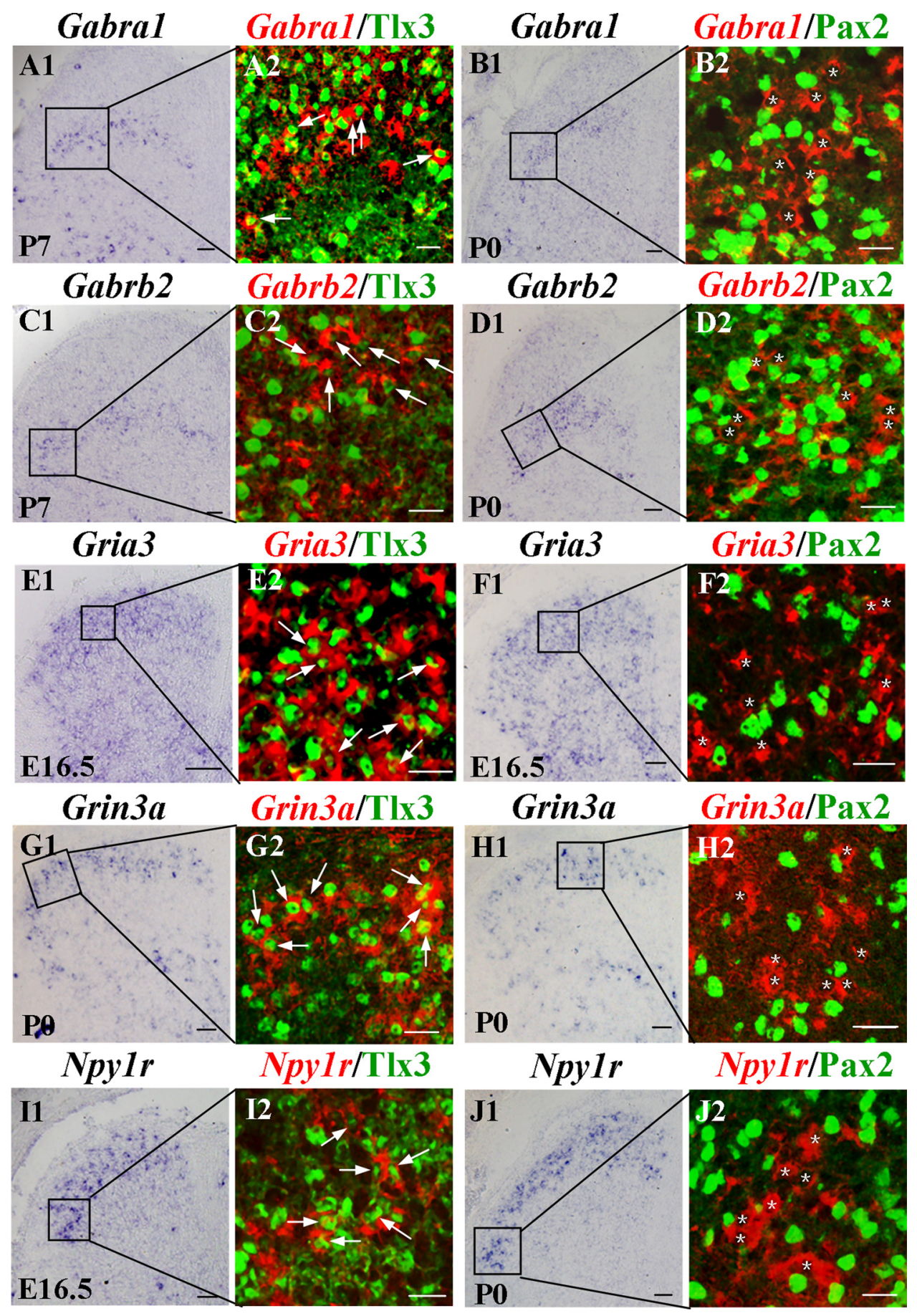

Figure 2. Expression of receptor/subunit genes Gabra1, Gabrb2, Gria3, Grin3a, and Npy1r in T1x3 ${ }^{+}$or Pax2 ${ }^{+}$neurons. A1- $\mathbf{J 2}$, Double staining of T|x3 protein (A2, C2, E2, G2, I2, green) or Pax2 protein (B2, D2 , F2, H2, J2, green) with Gabra1 (A2, B2, red), Gabrb2 (C2, D2, red), Gria3 (E2, F2, red), Grin3a (G2, $\mathbf{H 2}$, red), or Npy1r (I2, J2, red) mRNA on spinal cord sections at indicated stages. Bright-field in situ hybridization signals were converted into red pseudocolor signals. Note the colocalization of Gabra1, Gabrb2, Gria3, Grin3a, and Npy1r with T1x3 (A2, C2, E2, G2, I2, arrows) but not with Pax2 (B2, D2, F2, H2, J2). Scale bars: A1, B1, C1, D1, E1, F1, G1, H1, I1, J1, $50 \mu \mathrm{m} ; A 2, B 2, C 2, D 2, E 2, F 2$, G2, H2, I2, J2, $20 \mu \mathrm{m}$.

receptor family is composed of seven subunits, GluN1, GluN2A-GluN2D, GluN3A, and GluN3B, which are encoded by Grin1, Grin2a-Grin2d, Grin3a, and Grin3b, respectively (Cull-Candy et al., 2001). Subunits for metabotropic glutamate receptors include mGluR1-mGluR8, which are encoded by Grm1-Grm8 (Niswender and Conn, 2010). Receptors for GABA can be divided into ionotropic $\mathrm{GABA}_{\mathrm{A}}$ receptors and metabotropic $\mathrm{GABA}_{\mathrm{B}}$ receptors. The $\mathrm{GABA}_{\mathrm{A}}$ receptors are composed from 19 subunits, including $\alpha 1-\alpha 6, \beta 1-\beta 3, \gamma 1-\gamma 3$, $\delta, \varepsilon, \pi, \theta$, and $\rho 1-\rho 3$, which are encoded by genes Gabra1Gabra6, Gabrb1-Gabrb3, Gabrg1-Gabrg3, Gabrd, Gabre, Gabrp, Gabrq, and Gabrr1-Gabrr3, respectively (Barnard et al., 1998; Steiger and Russek, 2004). The $\mathrm{GABA}_{\mathrm{B}}$ receptors include $G_{A B A}$ and $G_{B B A}$, which are encoded by Gabbr1 and Gabbr2 (Bettler and Tiao, 2006). The glycine receptors consist of four $\alpha$ subunits $(\alpha 1-\alpha 4)$ and one $\beta$ subunit. Four genes, Glra1-Glra4, encode the $\alpha$ subunits, and one Glrb encodes the $\beta$ subunit (Lynch, 2004). 
For neuropeptides, there are three G-protein-coupled receptor (GPCR) subtypes for GAL: $\mathrm{Gal}_{1}, \mathrm{Gal}_{2}$, and $\mathrm{Gal}_{3}$, which are encoded by Galr1, Galr2, and Galr3, respectively (Branchek et al., 2000; Foord et al., 2005). SOM acts via a family of GPCRs, sst $_{1}-$ sst $_{5}$, which are encoded by Sstr1-Sstr5 (Csaba and Dournaud, 2001; Foord et al., 2005). NPY exerts its effects through activation of the G-protein-coupled $\mathrm{Y}$ receptors, notably $\mathrm{Y}_{1}, \mathrm{Y}_{2}, \mathrm{Y}_{4}$, and $\mathrm{Y}_{5}$, which are encoded by Npy1r, Npy2r, Ppyr1, and Npy5r, respectively (Blomqvist and Herzog, 1997; Foord et al., 2005). GRP binds with high affinity to its receptor GRPR, which is encoded by Grpr (Foord et al., 2005; Roesler et al., 2006). We also examined the expression of the receptor genes for CCK, TAK, PACAP, NT, and opioids (Wank, 1995; Vincent et al., 1999; Almeida et al., 2004; Foord et al., 2005; Dickson and Finlayson, 2009; Dietis et al., 2011).

We performed in situ hybridization experiments to detect the presence of 78 receptor/subunit genes in the spinal cord sections at E14.5, E16.5, P0, and P7. The results revealed that the expression patterns of different receptor/subunit genes in the developing dorsal horn were quite diverse. We used a simple code to indicate the expression patterns of receptor genes in the dorsal horn at P0: italic for those genes not expressed or very weakly expressed; bold for those genes with lamina-enriched expression pattern; and underlining for those genes with scattered expression pattern (Table 1). Figure 1 shows the spatial and temporal expression patterns of some representative receptor/subunit genes. Two features are noteworthy. First, expression of different genes was established at distinct developmental stages. In the dorsal spinal cord, Grm3, Grin3a, Sstr2, and Npy1r were expressed at E14.5. However, the expression of Gabra1 and Gabrb2 was initiated at approximately E16.5. Second, each receptor/subunit gene exhibited a unique lamina-specific expression pattern. Specifically, the expression of Gabra1, Gabrb2, and Grm3 was enriched in laminae II/III, whereas the expression of Grin3a, Sstr2, and Npy1r was enriched in the superficial laminae at P0 and P7.

\section{Glutamatergic and GABAergic neurons express two distinct sets of receptors}

We previously demonstrated that $\mathrm{Tlx}^{+}{ }^{+}$and $\mathrm{Pax} 2{ }^{+}$neurons are glutamatergic and GABAergic neurons, respectively, in the dorsal spinal cord (Cheng et al., 2004). To better understand the relationship between transcriptional regulators and the receptor gene expression, we undertook double-staining experiments that combined in situ hybridization (with receptor gene cDNAs as the probes) and immunostaining with antibodies against Tlx3 or Pax2. We found that receptor/subunit genes Gabra1, Gabra5, Gabrb2, Gria3, Grin3a, Grin3b, Galr1, and Npy1r were mainly expressed in $\mathrm{Tlx}^{+}$glutamatergic neurons. In contrast, these receptor/subunit genes were rarely expressed in Pax $2{ }^{+}$GABAergic neurons (Fig. 2 and data not shown). The localization of the receptors in glutamatergic neurons were confirmed in the following fate-mapping experiments. These experiments were performed on crosses between Tlx3-Cre and Tau-nLacZ mice. In the absence of Cre, the expression of the reporter gene $\beta$ galactosidase linked to a nuclear localization signal (nLacZ) was prevented by a transcriptional termination cassette. After Cremediated removal of the transcriptional termination cassette, the reporter $\mathrm{nLacZ}$ was expressed under the pan-neuronal Tau promoter (Fig. 3 and data not shown). A previous study has shown that nLacZ can be used for revealing both persistent and transient expression of Tlx3 (Xu et al., 2008). As described below, the complete or marked loss of the expression of receptor genes in $T l \times 1 / 3$

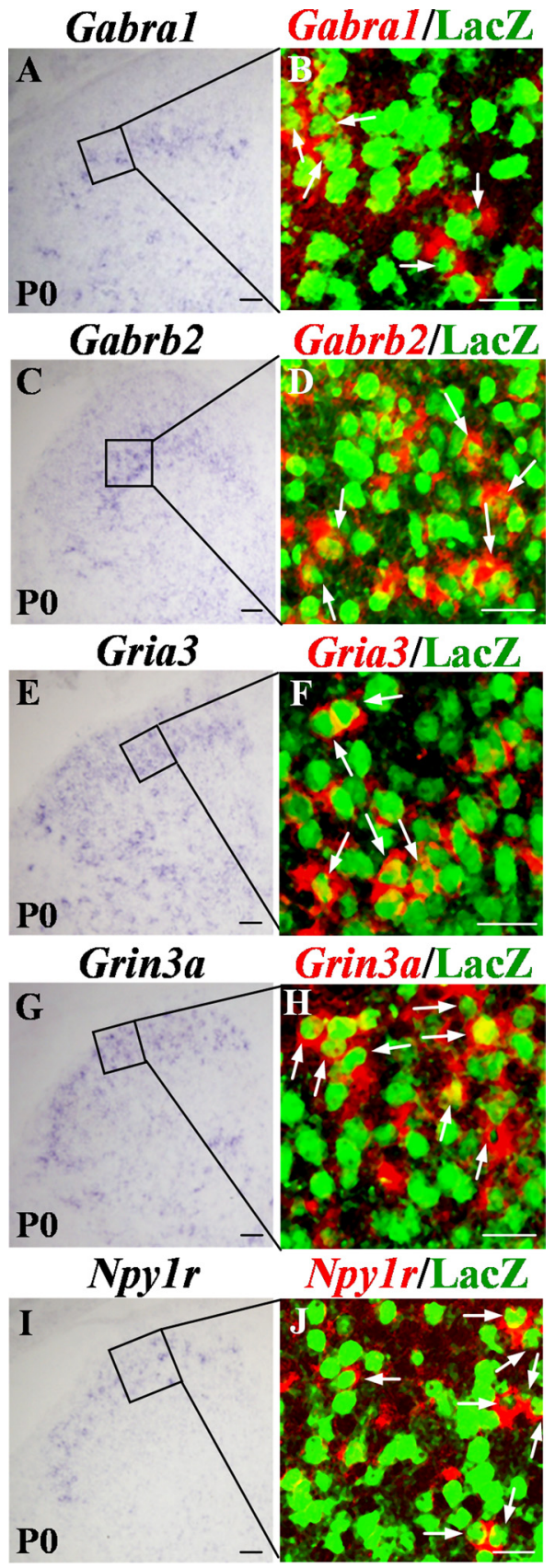

Figure 3. Expression of Gabra1, Gabrb2, Gria3, Grin3a, and Npy1rin Tlx3 ${ }^{+}$derivatives. $A-J$, Double staining of LacZ protein with Gabra1, Gabrb2, Gria3, Grin3a, or Npy1r on spinal sections of Tau-nLacZ $\left(T / \times 3^{c r e}\right)$ mice at P0. LacZ ${ }^{+}$neurons represent TIX3 ${ }^{+}$derivatives. Bright-field in situ hybridization signals were converted into red pseudocolor signals. Note the colocalization of Gabra1, Gabrb2, Gria3, Grin3a, and Npy1r with LacZ (B, D, F, H, J, arrows) in the dorsal horn. Scale bars: $\boldsymbol{A}, \boldsymbol{C}, \boldsymbol{E}, \mathbf{G}, \boldsymbol{I}, 50 \mu \mathrm{m} ; \boldsymbol{B}, \boldsymbol{D}, \boldsymbol{F}, \boldsymbol{H}, \boldsymbol{J}, 20 \mu \mathrm{m}$.

deletion mice suggests that the receptor genes are expressed in neurons with persistent or transient Tlx3 expression.

For receptor genes Grm3, Grm4, Grm5, Grik1, and Sstr2, we found that they were mainly expressed in $\mathrm{Pax} 2{ }^{+}$GABAergic neurons and rarely expressed in Tlx $3^{+}$glutamatergic neurons (Fig. 4 and data not shown). Meanwhile, we showed previously that the receptor genes Grik2 and Grik3 were preferentially expressed in Pax2 ${ }^{+}$GABAergic neurons (Cheng et al., 2004). Therefore, a distinct set of receptor/subunit genes, Grik1, Grik2, Grik3, Grm3, Grm4, Grm5, and Sstr2, were primarily expressed in Pax2 ${ }^{+}$ GABAergic neurons in the dorsal spinal cord. 


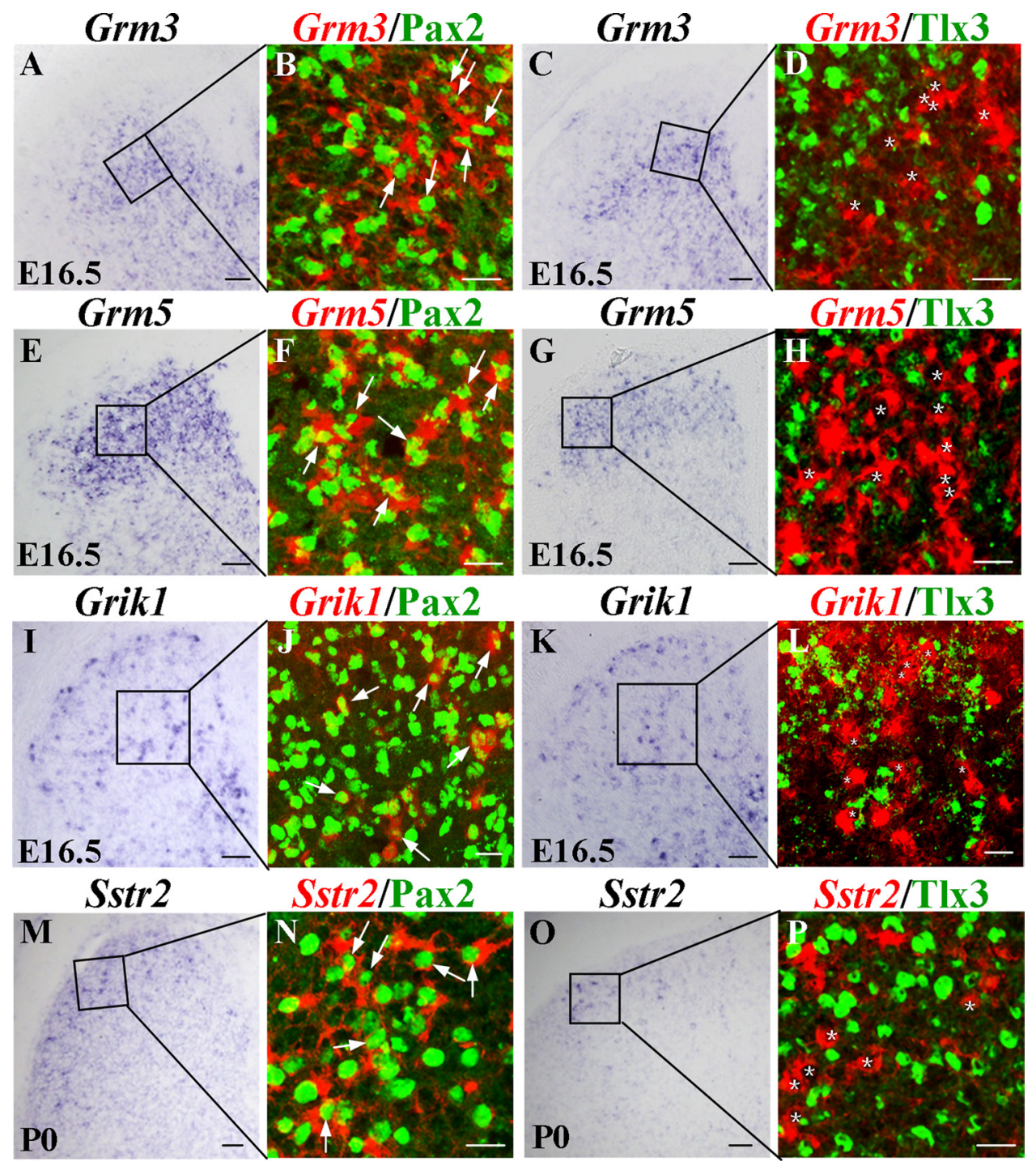

Figure 4. Expression of Grm3, Grm5, Grik1, and Sstr2 in Pax $2^{+}$or Tlx ${ }^{+}$neurons. $\boldsymbol{A}-\boldsymbol{P}$, Double staining of Pax2 protein $(\boldsymbol{B}, \boldsymbol{F}, \boldsymbol{J}, \boldsymbol{N}$, green) or Tlx3 protein $(\boldsymbol{D}, \boldsymbol{H}, \boldsymbol{L}, \boldsymbol{P}$, green) with $G r m 3(\boldsymbol{B}, \boldsymbol{D}$, red), $\operatorname{Grm5}(\boldsymbol{F}, \boldsymbol{H}$, red), Grik1 $(\boldsymbol{J}, \boldsymbol{L}$, red), or Sstr2 $(\boldsymbol{N}, \boldsymbol{P}$, red) mRNA on spinal cord sections at indicated stages. Bright-field in situ hybridization signals were converted into red pseudocolor signals. Note the colocalization of Grm3, Grm5, Grik1, and Sstr2 with Pax2 (B, F, J, N, arrows) but not TIx3 (D, H, L, P). Scale bars: A, C, E, G, I, K, M, O, $50 \mu \mathrm{m} ; \boldsymbol{B}, \boldsymbol{D}, \boldsymbol{F}, \boldsymbol{H}, \boldsymbol{J}, \mathbf{L}, \boldsymbol{N}, \boldsymbol{P}, 20 \mu \mathrm{m}$.

$T l x 1 / 3$ are required for expression of a subset of receptor genes

We next analyzed receptor gene expression in mice that lacked both $T l \times 3$ and its related gene Tlxl, because Tlx3 and Tlx1 exhibit a partial redundancy in cervical and thoracic spinal cord (Cheng et al., 2004). Expression of Gabra1, Gabra5, Gabrb2, Gria3, Grin3a, Grin3b, Galr1, and Npy1r was virtually eliminated or greatly reduced in Tlx1 and Tlx3 double-knockout $\left(T l \times 1 / 3^{-/-}\right)$mice at E14.5, E16.5, or E18.5 (Fig. 5A-J and data not shown). Meanwhile, it was shown previously that, within lamina I of the dorsal horn, SP receptor $\mathrm{NK}_{1}$ is restricted to neurons that are not GABAergic immunoreactive and that are likely to be excitatory (Littlewood et al., 1995). Therefore, we examined the expression of Tacrl, which encodes $\mathrm{NK}_{1}$, in Tlx1/3 deletion mice. In situ hybridization results showed that the expression of Tacrl disappeared in lamina I neurons of the dorsal horn of Tlx $1 / 3$ mutant mice at E18.5 (data not shown). Because increased cell death was not observed in $T l \times 1 / 3^{-1-}$ spinal cord at embryonic stages (Qian et al., 2002), the present results support the idea that $T l \times 1 / 3$ are required for the expression of these receptor genes.
Markers for spinal GABAergic neurons, including Pax2, Gad1/2, Viaat, and Grik2/3, are de-repressed in $T l \times 1 / 3^{-1-}$ mice (Cheng et al., 2004). We thus further examined whether the receptor genes found to be expressed in GABAergic neurons were also de-repressed in $T l \times 1 / 3^{-/-}$mice. In situ hybridization results showed that the numbers of neurons expressing Grm3, Grm4, Grm5, and Grik1 were increased in $T l \times 1 / 3^{-1-}$ mice (Fig. $5 \mathrm{~K}, L$ and data not shown). The number of $\mathrm{Grm} 3^{+}$cells per quadrant increased from $140 \pm 14$ in wild-type mice to $231 \pm 16$ in Tlx 1 and $T l \times 3$ deletion mice. However, the expression of the receptor gene Sstr2 was comparable in $T l \times 1 / 3^{-/-}$and wild-type control mice (data not shown). This result suggests that $T l x 1$ and $T l \times 3$ are required only for the suppression of a subset of GABAergic neuron markers.

Tlx 3 uses distinct pathways to control expression of different receptors

In dorsal spinal cord, Tlx 3 specifies the glutamatergic transmitter phenotype by antagonizing $L b x 1$ (Cheng et al., 2005). The expression of VGLUT2, which encodes vesicular glutamate transporter VGLUT2, and Tac1 and CCK, which encode two peptides (SP 


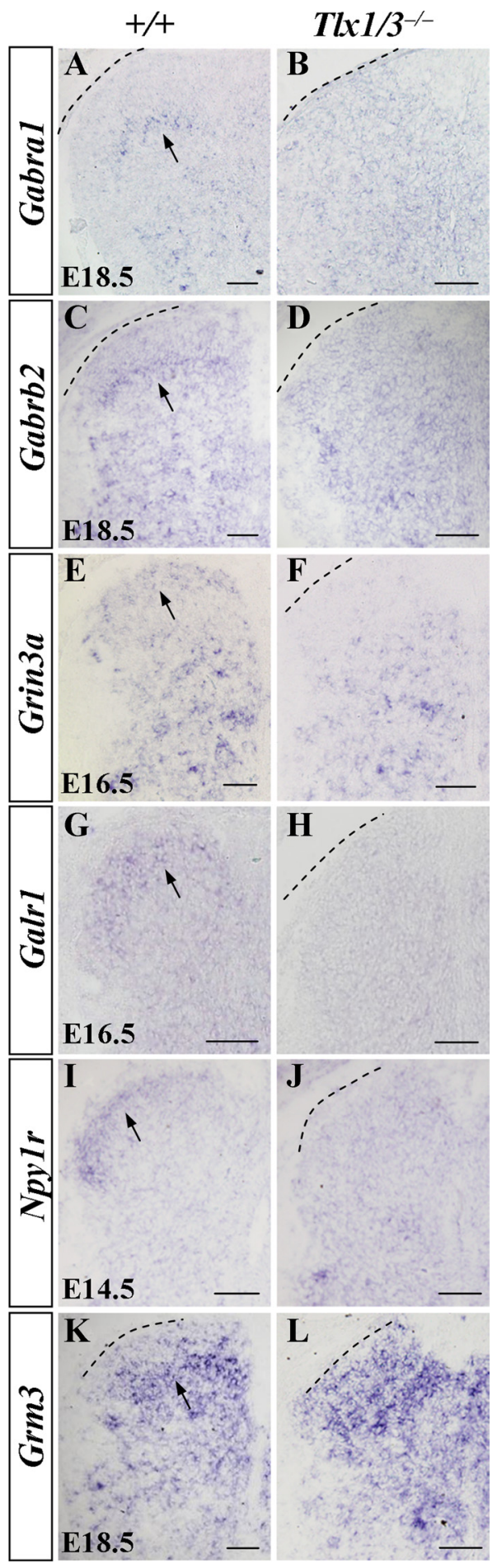

Figure 5. Expression of receptor/subunit genes in $T / x 1 / 3^{-/-}$mice. $A-L$, In situ hybridization was performed on sections of wild-type or $T / x 1 / 3^{-/-}$spinal cord at E14.5, E16.5, or E18.5. A-J, Note the loss of expression of Gabra1, Gabrb2, Grin3a, Galr1, and Npy1r in the dorsal horn of $T / x 1 / 3^{-/-}$mice (arrows). $K, \boldsymbol{L}$, Note the increase of $\mathrm{Grm} 3$ expression in the dorsal horn of $T / \times 1 / 3^{-/-}$mice (arrow). Scale bars, $100 \mu \mathrm{m}$.

and CCK), were found to be controlled by Tlx3 via distinct pathways (Xu et al., 2008). We also examined how Tlx1/3 may control the expression of various receptor genes. We analyzed receptor gene expression in $T l \times 3^{-1-}$ and $L b \times 1^{-/-}$single knock-out mice and $T l \times 3^{-1-} ; L b x 1^{-/-}$double-knock-out mice at E14.5, before the onset of cell death in the caudal spinal cord of $L b x 1^{-\prime-}$ mice (Gross et al., 2002; Cheng et al., 2005).
We found that the expression of Gria2, Galr1, and Npy1r was eliminated in $T l \times 3^{-/-}$and $L b x 1^{-/-}$mice and $T l \times 3^{-/-} ; L_{b x} 1^{-/-}$ mice, indicating that both $L b x 1$ and $T l x 3$ are required for the expression of these receptor genes (Fig. 6A-L). Expression of Gria 3 was greatly reduced in $T l \times 3^{-1-}$ mice but de-repressed in $L b x 1^{-/-}$mice. Furthermore, similar to the restoration of VGLUT2 expression, Gria 3 expression was recovered in $T l \times 3^{-1-}$; $L b x 1^{-1-}$ mice, indicating that $T l x 3$ antagonizes $L b x 1$ to promote the expression of Gria3 (Fig. $6 M-P$ ). These results suggest that Tlx 3 uses distinct pathways to control the expression of receptor genes.

\section{$P t f 1 a$ and Pax 2 are required for expression of a subset of receptor genes}

The transcription factor Ptfla promotes GABAergic cell differentiation and suppresses the glutamatergic cell fate via inhibiting Tlx3 expression (Glasgow et al., 2005), and Pax2 that lies downstream of Ptfla is required specifically for GABAergic differentiation (Cheng et al., 2004; Glasgow et al., 2005). Both Ptfla and Pax2 are also required for the expression of a specific set of peptides in GABAergic neurons (Bröhl et al., 2008; Huang et al., 2008). We therefore examined whether Ptfla and Pax2 control the receptor genes that are localized in GABAergic neurons. In situ hybridization results showed that the expression of Grik1, Grik2, Grik3, Grm3, Grm4, Grm5, and Sstr2 was eliminated or markedly reduced in the dorsal horn of $\mathrm{Ptfla}^{-1-}$ mice (Fig. 7A-J and data not shown) and $\mathrm{Pax}^{-/-}$embryos (Fig. 8 and data not shown).

Because glutamatergic neurons are increased in $\mathrm{Ptfla} \mathrm{a}^{-/-}$mice (Glasgow et al., 2005), we examined whether the expression of the receptors that are localized in glutamatergic neurons are derepressed in $\mathrm{Ptfla}^{-/-}$embryos. In situ hybridization results showed that the expression of Gabra5, Gabrb2, and Npylr was indeed de-repressed in the $P t f 1 a^{-1-}$ mice, whereas the expression of Gria2, Gria3, Grin3a, Grin3b, Gabra1, Galr1, and Tacr1 was comparable in $\mathrm{Ptfla}^{-1-}$ and wild-type mice (Fig. $7 \mathrm{~K}, \mathrm{~L}$ and data not shown). The number of $N p y 1 r^{+}$cells per quadrant increased from $49 \pm 5$ in wild-type mice to $69 \pm 6$ in Ptfla deletion mice $(p<0.01)$.

\section{Discussion}

In this study, we screened expression of 78 receptor/subunits for glutamate, GABA, glycine, and peptides in the dorsal spinal cord by in situ hybridization and found that two distinct sets of receptor/subunit genes were preferentially expressed in glutamatergic versus GABAergic neurons. By analyzing the knock-out mice, we found that transcription factors $T / x 1 / 3$, which determine the glutamatergic cell fate, control the expression of a selective set of receptor/subunit genes in glutamatergic neurons, including $\mathrm{Ga}$ bra1, Gabra5, Gabrb2, Gria3, Grin3a, Grin3b, Galr1, Npy1r, and Tacr1. In contrast, transcription factors Ptf1a and Pax2, which are required for the GABAergic differentiation, control the expression of another set of receptor/subunit genes in GABAergic neurons, including Grik1, Grik2, Grik3, Grm3, Grm4, Grm5, and Sstr2. Furthermore, we obtained genetic evidence that $T l x 1$ and Tlx 3 used distinct mechanisms to control the expression of different receptor/subunit genes.

\section{Transmitter and peptide receptor gene expression in dorsal spinal cord}

Our present study shows that two distinct sets of transmitter and peptide receptor/subunit genes are preferentially enriched in excitatory and inhibitory neurons, respectively, in the dorsal horn 


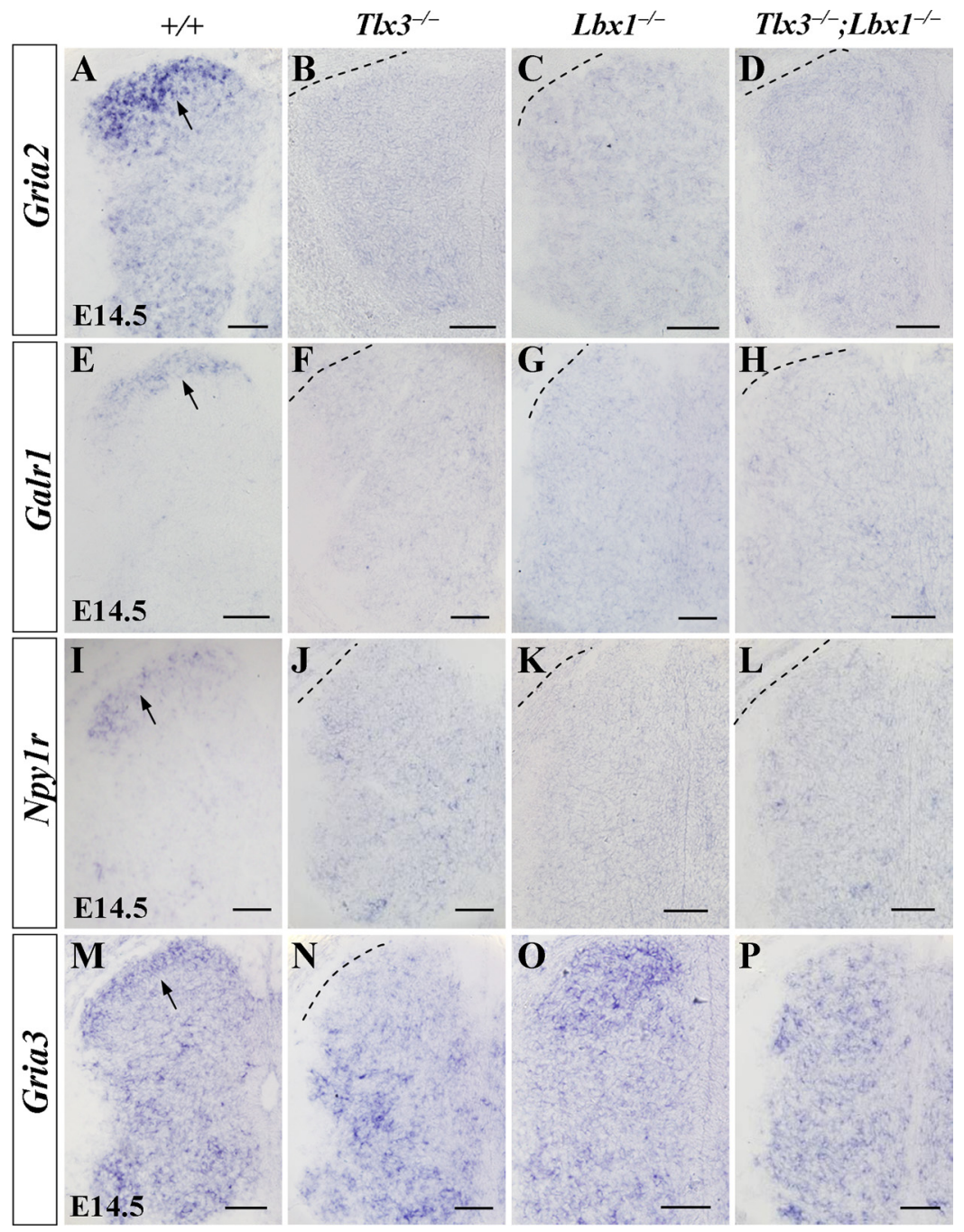

Figure 6. Expression of receptor/subunit genes in $T / x 3^{-/-}, L b x 1^{-1-}$, and $T / x 3^{-1-} ; L b x 1^{-1-}$ mice. $A-P$, In situ hybridization was performed on sections of spinal cord from E14.5 embryos (with indicated genotypes). $A-L$, Note the loss of expression of Gria2, Galr1, and Npy $1 r$ in the superficial laminae of the dorsal horn in $T / x 3^{-/-}, L b \times 1^{-/-}$, and $T / x 3^{-/-} ; L b \times 1^{-/-}$mice (arrows). $M-P$, Gria3 expression was markedly reduced in the dorsal horn of $T / x 3^{-/-}$mice, de-repressed in the dorsal horn of $L b x 1^{-/-}$mice, and restored in the dorsal horn of $T / x 3^{-/-} ; L b x 1^{-/-}$mice. Scale bars, $100 \mu \mathrm{m}$.

and are controlled by transcription factors that specify the excitatory and inhibitory cell fate. The receptor genes Gabra1, Gabra5, Gabrb2, Gria3, Grin3a, Grin3b, Galr1, Npy1r, and Tacr1 (Littlewood et al., 1995) are mainly expressed in glutamatergic neurons in the dorsal horn, and, together with receptor gene Gria2 (Cheng et al., 2004), they are controlled by transcription factors Tlx1/3 (Figs. 2, 3, 5, 9 and data not shown). Transcription factor $L b x 1$ is required for the expression of receptor genes Gria2, Galr1, and Npy1r, whereas it suppresses the expression of receptor gene Gria3 (Figs. 6, 9). Meanwhile, the expression of Gabra5, Gabrb2, and Npy1r are suppressed by Ptfla in the dorsal horn (Figs. $7 K, L, 9$ and data not shown). The above results are in line with the reports that receptor genes Galr1 and Npylr are expressed in glutamatergic neurons (Brumovsky et al., 2006; Landry et al., 2006). Conversely, although nearly all of the GluA2/GluA3-immunoreactive neurons did not contain GABA or glycine, it was not determined whether receptor subunit GluA3 was expressed in glutamatergic neurons because the antibody used detected an epitope common to both GluA2 and GluA3 (Spike et al., 1998).

The receptor genes Grik1, Grm3, Grm4, Grm5, and Sstr2 are expressed in GABAergic neurons in the dorsal horn, and, together with the receptor genes Grik2 and Grik3 (Cheng et al.,
2004), they are controlled by transcription factors Ptfla and Pax2 (Figs. 4, 7-9 and data not shown). Meanwhile, the expression of Grik1, Grm3, Grm4, and Grm5, together with receptor genes Grik2 and Grik3 (Cheng et al., 2004), are repressed by transcription factors Tlx1/3 (Figs. $5 K, L, 9$ and data not shown). Expression of receptors GluK1, mGluR3, mGluR5, and sst $_{2}$ has been demonstrated in GABAergic neurons in the dorsal horn (Todd et al., 1998; Jia et al., 1999; Lu et al., 2005). Furthermore, a recent study provided functional evidence that SOM receptors (presumably $\mathrm{sst}_{2}$ ) were restricted to GABAergic interneurons (Yasaka et al., 2010).

Expression of some peptide genes is restricted to excitatory or inhibitory neurons as well. SOM is mainly expressed in excitatory neurons in superficial laminae (Proudlock et al., 1993; Todd et al., 2003), whereas its receptor $s t_{2}$ is mainly expressed in inhibitory neurons (Todd et al., 1998; Yasaka et al., 2010). A reverse situation exists for peptides NPY and GAL and their receptors $\mathrm{Y}_{1}$ and $\mathrm{Gal}_{1}$ (Rowan et al., 1993; Simmons et al., 1995; Zhang et al., 1999; Brumovsky et al., 2006; Landry et al., 2006), indicating a direct crosstalk between excitatory and inhibitory neurons. The potential interaction between excitatory and inhibitory neurons is further corroborated by the fact that several glutamate receptor/subunit genes are enriched in inhibitory neurons, and several receptors for GABA are 


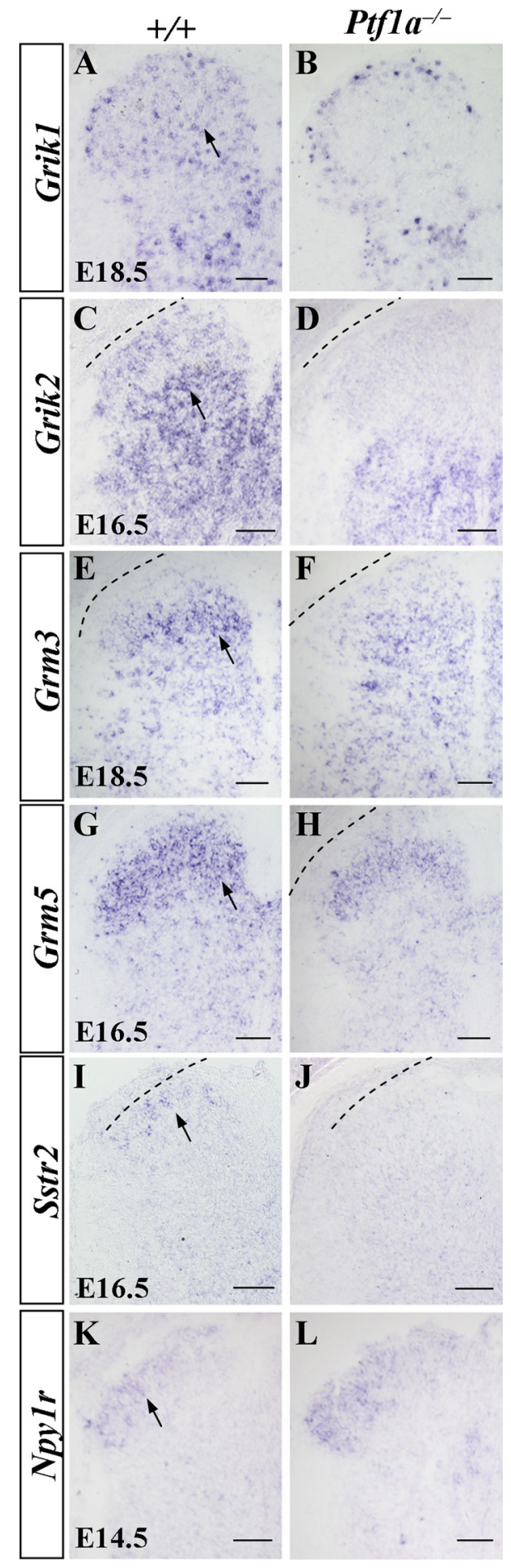

Figure 7. Expression of receptor/subunit genes Grik1, Grik2, Grm3, Grm5, Sstr2, and Npy1rin Ptf1a ${ }^{-/-}$mice. $A-L$, In situ hybridization was performed on spinal cord sections of wild-type or Ptf1a ${ }^{-/-}$mice at E14.5, E16.5, or E18.5. A-J, Note the loss or reduction of expression of Grik1, Grik2, Grm3, Grm5, and Sstr2 in the dorsal horn of Ptf1a ${ }^{-1-}$ mice (arrows). $\boldsymbol{K}, \boldsymbol{L}$, Note the increase of Npy 1 r expression in the dorsal horn of $\mathrm{Ptfla}^{-/-}$mice (arrow). Scale bars, $100 \mu \mathrm{m}$.

selectively enriched in excitatory neurons (Jia et al., 1999; Kerchner et al., 2002; Cheng et al., 2004; Lu et al., 2005).

\section{Diverse pathways regulating expression of VGLUT2, Tac1/ $C C K$, and glutamate/peptide receptors}

We demonstrated previously that transcription factors $T l \times 1 / 3$ antagonize transcription factor $L b x 1$ to promote the expression of

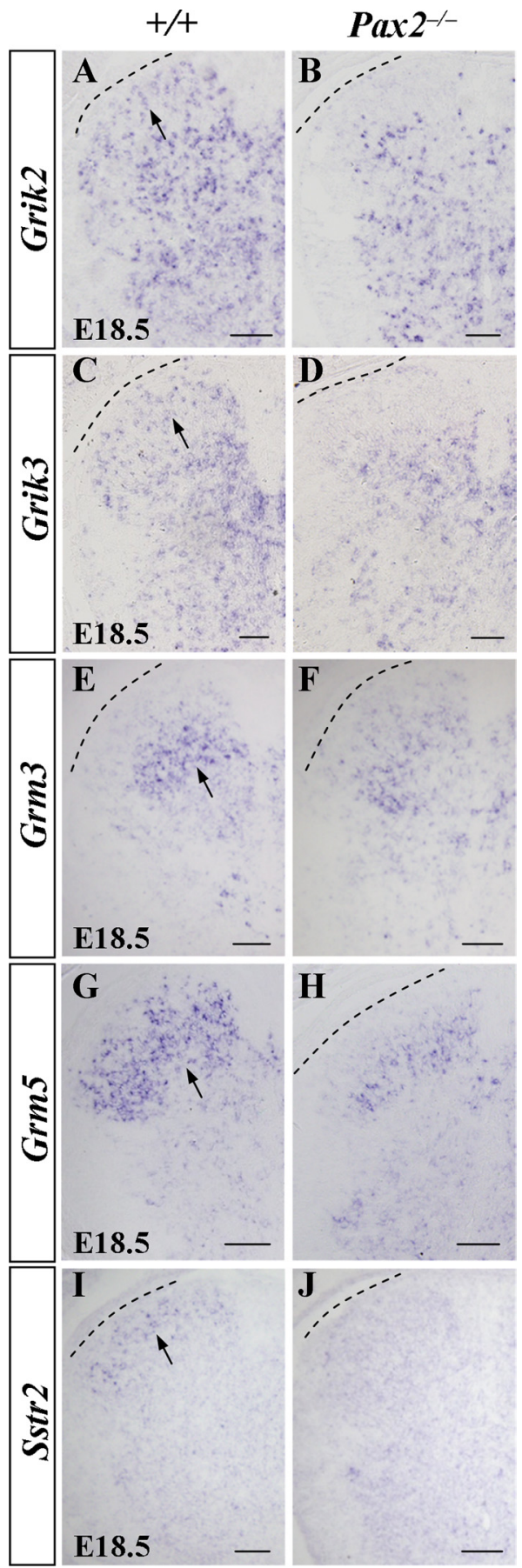

Figure 8. Expression of receptor/subunit genes Grik2, Grik3, Grm3, Grm5, and Sstr2 in Pax2 ${ }^{-/-}$mice. $A-J$, In situ hybridization was performed on sections of spinal cord from wildtype or Pax2 ${ }^{-1-}$ mice at E18.5. Note the loss or marked reduction of expression of Grik2, Grik3, Grm3, Grm5, and Sstr2 in the dorsal horn of Pax2 ${ }^{-1-}$ mice. Scale bars, $100 \mu \mathrm{m}$.

VGLUT2, a vesicular glutamate transporter that has served as a specific marker for glutamatergic neurons, in the spinal dorsal horn (Cheng et al., 2005). Loss of VGLUT2 expression in Tlx3 mutant mice is restored in $T l \times 3^{-/-} ; L b \times 1^{-/-}$double-mutant mice (Cheng et al., 2005). Because expression of the Tlx1/3-dependent peptide genes is not restored in $T l \times 3^{-1-} ; L b x 1^{-1-}$ double-mutant mice, we proposed that $T l \times 1 / 3$ use distinct pathways to coordinate glutamate and peptide transmitters (Tacl/CCK) (Xu et al., 2008). Here we provide genetic evidence that $T l \times 1 / 3$ control the expression of receptor genes via different mechanisms. Expres- 
sion of receptor genes Gria2, Galr1, and Npy1r depended on both $L b x 1$ and Tlx3 despite the fact that $T l \times 3$ antagonized Lbx1 to promote VGLUT2 expression (Cheng et al., 2005; Figs. 6A-L, 9). Conversely, loss of expression of Gria3 in Tlx3 mutant was restored in $T l \times 3^{-/-} ; L b \times 1^{-/-}$ double-mutant mice and the expression of Gria3 was de-repressed in $L b \times 1^{-1-}$ mice, implying that $T l x 3$ antagonizes $L b x 1$ to promote the expression of Gria3 as well (Figs. 6M-P, 9). Therefore, $T l \times 3$ controls the expression of glutamatergic cell fate marker VGLUT2, peptide genes, and receptor genes for transmitters and peptides in glutamatergic neurons by several different mechanisms: $T l x 3$ antagonizes $L b \times 1$ to promote the expression of VGLUT2 and Gria3; Tlx3 controls the expression of peptide gene Tac1 through an Lbx1independent pathway; and both $T l x 3$ and Lbx1 are required for the expression of peptide gene $C C K$, receptor genes Gria2, Galr1, and Npy1r (Cheng et al., 2005; Xu et al., 2008; this study).

\section{Potential role of selector genes in controlling expression of receptor genes}

Selector genes are a class of genes that control the fates of groups of cells during development (García-Bellido, 1975; Mann and Carroll, 2002). Selector genes typically make a choice between two alternative fates by activating sets of genes that are expressed in a particular cell type, tissue, organ, or region, while at the same time suppressing the genes associated with alternative fates (Mann and Carroll, 2002). Tlx1/3 and Ptfla are selector genes known to determine the glutamatergic and GABAergic fates in the dorsal horn of the spinal cord, respectively (Cheng et al., 2004; Glasgow et al., 2005). Furthermore, they control the expression of peptides that are preferentially distributed in excitatory and inhibitory neurons in the dorsal spinal cord, respectively (Bröhl et al., 2008; Huang et al., 2008; Xu et al., 2008). Our findings here provide the evidence that two distinct sets of transmitter and peptide receptor genes are expressed in glutamatergic or GABAergic neurons and controlled by $T l x 1 / 3$ or $P t f 1 a$. It will be of interest to examine whether other neuronal selector genes control the expression of region-specific transmitter and peptide receptor genes (Puelles et al., 2006; Sieber et al., 2007; Mangale et al., 2008).

\section{Physiological implications of neuronal type-specific expression of receptors}

Dorsal horn neurons in the spinal cord receive somatic information, such as pain, temperature, itch, and touch, from the peripheral tissues. After the sensory signal is received in the dorsal horn, the information is transmitted to higher centers in the CNS by projection neurons (Renn and Dorsey, 2005). Electrophysiological investigations have shown that glutamate is the principal excitatory transmitter of primary afferent fibers (Yoshimura and
Jessell, 1990; Li et al., 1999). This is corroborated by a recent study that showed that glutamate acts as a transmitter for itch synaptic transmission in the spinal cord (Koga et al., 2011). The output neurons of the dorsal horn are projection neurons, which are concentrated in lamina I and scattered throughout laminae III/ VI, and relay sensory information to several brain areas. The vast majority of neurons in the dorsal horn are local circuit interneurons that do not project outside of the spinal cord. Thus, the output of projection neurons is influenced by local excitatory and inhibitory neurons (Todd, 2010; Larsson and Broman, 2011). The balance between excitation and inhibition is crucial for maintaining normal sensory function (Basbaum et al., 2009; Costigan et al., 2009; Ross et al., 2010; Takazawa and MacDermott, 2010). Among the two distinct sets of transmitter and peptide receptors, deletion of Npy1r results in a pronounced mechanical hypersensitivity, suggesting that Npy1r plays an important role in the control of transmission of sensory information (Naveilhan et al., 2001; Shi et al., 2006). However, the physiological roles played by other receptors in the dorsal horn needs to be further examined.

Despite the importance of dorsal spinal cord in normal sensory processing and in pathological condition, our knowledge 
about the neuronal circuit that link incoming primary afferent to the projection neurons remains rather limited (Graham et al., 2007; Todd, 2010). Establishing the pattern of expression of receptors on different neuronal types will be essential for understanding the dorsal horn circuitry (Graham et al., 2007; Todd, 2010). In this regard, the finding that distinct sets of transmitter and peptide receptors that are preferentially distributed in glutamatergic or GABAergic neurons will provide useful clues for dissecting the circuitry of the dorsal spinal cord.

\section{References}

Almeida TA, Rojo J, Nieto PM, Pinto FM, Hernandez M, Martín JD, Candenas ML (2004) Tachykinins and tachykinin receptors: structure and activity relationships. Curr Med Chem 11:2045-2081.

Barnard EA, Skolnick P, Olsen RW, Mohler H, Sieghart W, Biggio G, Braestrup C, Bateson AN, Langer SZ (1998) International Union of Pharmacology. XV. Subtypes of gamma-aminobutyric acidA receptors: classification on the basis of subunit structure and receptor function. Pharmacol Rev 50:291-313.

Basbaum AI, Bautista DM, Scherrer G, Julius D (2009) Cellular and molecular mechanisms of pain. Cell 139:267-284.

Bennett MR, Balcar VJ (1999) Forty years of amino acid transmission in the brain. Neurochem Int 35:269-280.

Bettler B, Tiao JY (2006) Molecular diversity, trafficking and subcellular localization of GABAB receptors. Pharmacol Ther 110:533-543.

Blomqvist AG, Herzog H (1997) Y-receptor subtypes: how many more? Trends Neurosci 20:294-298.

Branchek TA, Smith KE, Gerald C, Walker MW (2000) Galanin receptor subtypes. Trends Pharmacol Sci 21:109-117.

Bröhl D, Strehle M, Wende H, Hori K, Bormuth I, Nave KA, Müller T, Birchmeier C (2008) A transcriptional network coordinately determines transmitter and peptidergic fate in the dorsal spinal cord. Dev Biol 322:381-393.

Brumovsky P, Hofstetter C, Olson L, Ohning G, Villar M, Hökfelt T (2006) The neuropeptide tyrosine $\mathrm{Y} 1 \mathrm{R}$ is expressed in interneurons and projection neurons in the dorsal horn and area $\mathrm{X}$ of the rat spinal cord. Neuroscience 138:1361-1376.

Caspary T, Anderson KV (2003) Patterning cell types in the dorsal spinal cord: what the mouse mutants say. Nat Rev Neurosci 4:289-297.

Cheng L, Arata A, Mizuguchi R, Qian Y, Karunaratne A, Gray PA, Arata S, Shirasawa S, Bouchard M, Luo P, Chen CL, Busslinger M, Goulding M, Onimaru H, Ma Q (2004) Tlx3 and Tlx1 are post-mitotic selector genes determining glutamatergic over GABAergic cell fates. Nat Neurosci 7:510-517.

Cheng L, Samad OA, Xu Y, Mizuguchi R, Luo P, Shirasawa S, Goulding M, Ma Q (2005) Lbx1 and Tlx3 are opposing switches in determining GABAergic versus glutamatergic transmitter phenotypes. Nat Neurosci 8:1510-1515.

Collingridge GL, Olsen RW, Peters J, Spedding M (2009) A nomenclature for ligand-gated ion channels. Neuropharmacology 56:2-5.

Contractor A, Mulle C, Swanson GT (2011) Kainate receptors coming of age: milestones of two decades of research. Trends Neurosci 34:154-163.

Costigan M, Scholz J, Woolf CJ (2009) Neuropathic pain: a maladaptive response of the nervous system to damage. Annu Rev Neurosci 32:1-32.

Csaba Z, Dournaud P (2001) Cellular biology of somatostatin receptors. Neuropeptides 35:1-23.

Cull-Candy S, Brickley S, Farrant M (2001) NMDA receptor subunits: diversity, development and disease. Curr Opin Neurobiol 11:327-335.

Dickson L, Finlayson K (2009) VPAC and PAC receptors: from ligands to function. Pharmacol Ther 121:294-316.

Dietis N, Rowbotham DJ, Lambert DG (2011) Opioid receptor subtypes: fact or artifact? Br J Anaesth 107:8-18.

Fitzgerald M (2005) The development of nociceptive circuits. Nat Rev Neurosci 6:507-520.

Foord SM, Bonner TI, Neubig RR, Rosser EM, Pin JP, Davenport AP, Spedding M, Harmar AJ (2005) International Union of Pharmacology. XLVI. G protein-coupled receptor list. Pharmacol Rev 57:279-288.

García-Bellido A (1975) Genetic control of wing disc development in Drosophila. Ciba Found Symp 0:161-182.

Glasgow SM, Henke RM, Macdonald RJ, Wright CV, Johnson JE (2005)
Ptfla determines GABAergic over glutamatergic neuronal cell fate in the spinal cord dorsal horn. Development 132:5461-5469.

Graham BA, Brichta AM, Callister RJ (2007) Moving from an averaged to specific view of spinal cord pain processing circuits. J Neurophysiol 98:1057-1063.

Gross MK, Moran-Rivard L, Velasquez T, Nakatsu MN, Jagla K, Goulding M (2000) Lbxl is required for muscle precursor migration along a lateral pathway into the limb. Development 127:413-424.

Gross MK, Dottori M, Goulding M (2002) Lbx1 specifies somatosensory association interneurons in the dorsal spinal cord. Neuron 34:535-549.

Helms AW, Johnson JE (2003) Specification of dorsal spinal cord interneurons. Curr Opin Neurobiol 13:42-49.

Hippenmeyer S, Vrieseling E, Sigrist M, Portmann T, Laengle C, Ladle DR, Arber S (2005) A developmental switch in the response of DRG neurons to ETS transcription factor signaling. PLoS Biol 3:e159.

Hori K, Cholewa-Waclaw J, Nakada Y, Glasgow SM, Masui T, Henke RM, Wildner H, Martarelli B, Beres TM, Epstein JA, Magnuson MA, Macdonald RJ, Birchmeier C, Johnson JE (2008) A nonclassical bHLH Rbpj transcription factor complex is required for specification of GABAergic neurons independent of Notch signaling. Genes Dev 22:166-178.

Huang M, Huang T, Xiang Y, Xie Z, Chen Y, Yan R, Xu J, Cheng L (2008) Ptfla, Lbx1 and Pax2 coordinate glycinergic and peptidergic transmitter phenotypes in dorsal spinal inhibitory neurons. Dev Biol 322:394-405.

Huang T, Liu Y, Huang M, Zhao X, Cheng L (2010) Wnt1-cre-mediated conditional loss of Dicer results in malformation of the midbrain and cerebellum and failure of neural crest and dopaminergic differentiation in mice. J Mol Cell Biol 2:152-163.

Jia H, Rustioni A, ValtschanoffJG (1999) Metabotropic glutamate receptors in superficial laminae of the rat dorsal horn. J Comp Neurol 410:627-642.

Kawaguchi Y, Cooper B, Gannon M, Ray M, MacDonald RJ, Wright CV (2002) The role of the transcriptional regulator Ptfla in converting intestinal to pancreatic progenitors. Nat Genet 32:128-134.

Kerchner GA, Wilding TJ, Huettner JE, Zhuo M (2002) Kainate receptor subunits underlying presynaptic regulation of transmitter release in the dorsal horn. J Neurosci 22:8010-8017.

Koga K, Chen T, Li XY, Descalzi G, Ling J, Gu J, Zhuo M (2011) Glutamate acts as a neurotransmitter for gastrin releasing peptide-sensitive and insensitive itch-related synaptic transmission in mammalian spinal cord. Mol Pain 7:47.

Landry M, Bouali-Benazzouz R, André C, Shi TJ, Léger C, Nagy F, Hökfelt T (2006) Galanin receptor 1 is expressed in a subpopulation of glutamatergic interneurons in the dorsal horn of the rat spinal cord. J Comp Neurol 499:391-403.

Larsson M, Broman J (2011) Synaptic plasticity and pain: role of ionotropic glutamate receptors. Neuroscientist 17:256-273.

Li MZ, Wang JS, Jiang DJ, Xiang CX, Wang FY, Zhang KH, Williams PR, Chen ZF (2006) Molecular mapping of developing dorsal hornenriched genes by microarray and dorsal/ventral subtractive screening. Dev Biol 292:555-564.

Li P, Wilding TJ, Kim SJ, Calejesan AA, Huettner JE, Zhuo M (1999) Kainate-receptor-mediated sensory synaptic transmission in mammalian spinal cord. Nature 397:161-164.

Littlewood NK, Todd AJ, Spike RC, Watt C, Shehab SA (1995) The types of neuron in spinal dorsal horn which possess neurokinin-1 receptors. Neuroscience 66:597-608.

Lodge D (2009) The history of the pharmacology and cloning of ionotropic glutamate receptors and the development of idiosyncratic nomenclature. Neuropharmacology 56:6-21.

Lu CR, Willcockson HH, Phend KD, Lucifora S, Darstein M, Valtschanoff JG, Rustioni A (2005) Ionotropic glutamate receptors are expressed in GABAergic terminals in the rat superficial dorsal horn. J Comp Neurol 486:169-178.

Lynch JW (2004) Molecular structure and function of the glycine receptor chloride channel. Physiol Rev 84:1051-1095.

Ma Q (2006) Transcriptional regulation of neuronal phenotype in mammals. J Physiol 575:379-387.

Mangale VS, Hirokawa KE, Satyaki PR, Gokulchandran N, Chikbire S, Subramanian L, Shetty AS, Martynoga B, Paul J, Mai MV, Li Y, Flanagan LA, Tole S, Monuki ES (2008) Lhx2 selector activity specifies cortical identity and suppresses hippocampal organizer fate. Science 319:304-309.

Mann RS, Carroll SB (2002) Molecular mechanisms of selector gene function and evolution. Curr Opin Genet Dev 12:592-600. 
Mizuguchi R, Kriks S, Cordes R, Gossler A, Ma Q, Goulding M (2006) Ascl1 and Gsh1/2 control inhibitory and excitatory cell fate in spinal sensory interneurons. Nat Neurosci 9:770-778.

Müller T, Anlag K, Wildner H, Britsch S, Treier M, Birchmeier C (2005) The bHLH factor Olig3 coordinates the specification of dorsal neurons in the spinal cord. Genes Dev 19:733-743.

Nakagawa T (2010) The biochemistry, ultrastructure, and subunit assembly mechanism of AMPA receptors. Mol Neurobiol 42:161-184.

Naveilhan P, Hassani H, Lucas G, Blakeman KH, Hao JX, Xu XJ, WiesenfeldHallin Z, Thorén P, Ernfors P (2001) Reduced antinociception and plasma extravasation in mice lacking a neuropeptide $\mathrm{Y}$ receptor. Nature 409:513-517.

Niswender CM, Conn PJ (2010) Metabotropic glutamate receptors: physiology, pharmacology, and disease. Annu Rev Pharmacol Toxicol 50:295-322.

Proudlock F, Spike RC, Todd AJ (1993) Immunocytochemical study of somatostatin, neurotensin, GABA, and glycine in rat spinal dorsal horn. J Comp Neurol 327:289-297.

Puelles E, Acampora D, Gogoi R, Tuorto F, Papalia A, Guillemot F, Ang SL, Simeone A (2006) Otx2 controls identity and fate of glutamatergic progenitors of the thalamus by repressing GABAergic differentiation. J Neurosci 26:5955-5964.

Qian Y, Shirasawa S, Chen CL, Cheng L, Ma Q (2002) Proper development of relay somatic sensory neurons and D2/D4 interneurons requires homeobox genes Rnx/Tlx-3 and Tlx-1. Genes Dev 16:1220-1233.

Renn CL, Dorsey SG (2005) The physiology and processing of pain: a review. AACN Clin Issues 16:277-290; quiz 413-415.

Roberts CW, Shutter JR, Korsmeyer SJ (1994) Hox11 controls the genesis of the spleen. Nature 368:747-749.

Roesler R, Henriques JA, Schwartsmann G (2006) Gastrin-releasing peptide receptor as a molecular target for psychiatric and neurological disorders. CNS Neurol Disord Drug Targets 5:197-204.

Ross SE, Mardinly AR, McCord AE, Zurawski J, Cohen S, Jung C, Hu L, Mok SI, Shah A, Savner EM, Tolias C, Corfas R, Chen S, Inquimbert P, Xu Y, McInnes RR, Rice FL, Corfas G, Ma Q, Woolf CJ, Greenberg ME (2010) Loss of inhibitory interneurons in the dorsal spinal cord and elevated itch in Bhlhb5 mutant mice. Neuron 65:886-898.

Rowan S, Todd AJ, Spike RC (1993) Evidence that neuropeptide Y is present in GABAergic neurons in the superficial dorsal horn of the rat spinal cord. Neuroscience 53:537-545.

Shi TJ, Li J, Dahlström A, Theodorsson E, Ceccatelli S, Decosterd I, Pedrazzini T, Hökfelt T (2006) Deletion of the neuropeptide Y Y1 receptor affects pain sensitivity, neuropeptide transport and expression, and dorsal root ganglion neuron numbers. Neuroscience 140:293-304.

Shirasawa S, Arata A, Onimaru H, Roth KA, Brown GA, Horning S, Arata S, Okumura K, Sasazuki T, Korsmeyer SJ (2000) Rnx deficiency results in congenital central hypoventilation. Nat Genet 24:287-290.

Sieber MA, Storm R, Martinez-de-la-Torre M, Müller T, Wende H, Reuter K, Vasyutina E, Birchmeier C (2007) Lbx1 acts as a selector gene in the fate determination of somatosensory and viscerosensory relay neurons in the hindbrain. J Neurosci 27:4902-4909.

Simmons DR, Spike RC, Todd AJ (1995) Galanin is contained in GABAergic neurons in the rat spinal dorsal horn. Neurosci Lett 187:119-122.

Spike RC, Kerr R, Maxwell DJ, Todd AJ (1998) GluR1 and GluR2/3 subunits of the AMPA-type glutamate receptor are associated with particular types of neurone in laminae I-III of the spinal dorsal horn of the rat. Eur J Neurosci 10:324-333.

Steiger JL, Russek SJ (2004) GABAA receptors: building the bridge between subunit mRNAs, their promoters, and cognate transcription factors. Pharmacol Ther 101:259-281.

Takazawa T, MacDermott AB (2010) Synaptic pathways and inhibitory gates in the spinal cord dorsal horn. Ann N Y Acad Sci 1198:153-158.

Todd AJ (2010) Neuronal circuitry for pain processing in the dorsal horn. Nat Rev Neurosci 11:823-836.

Todd AJ, Maxwell DJ (2000) GABA in the mammalian spinal cord. . In: GABA in the nervous system: the view at fifty years (Martin DL, Olsen RW, eds), pp 439-457. Philadelphia: Lippincott Williams and Wilkins.

Todd AJ, Spike RC (1993) The localization of classical transmitters and neuropeptides within neurons in laminae I-III of the mammalian spinal dorsal horn. Prog Neurobiol 41:609-645.

Todd AJ, Spike RC, Price RF, Neilson M (1994) Immunocytochemical evidence that neurotensin is present in glutamatergic neurons in the superficial dorsal horn of the rat. J Neurosci 14:774-784.

Todd AJ, Spike RC, Polgár E (1998) A quantitative study of neurons which express neurokinin- 1 or somatostatin sst2a receptor in rat spinal dorsal horn. Neuroscience 85:459-473.

Todd AJ, Hughes DI, Polgár E, Nagy GG, Mackie M, Ottersen OP, Maxwell DJ (2003) The expression of vesicular glutamate transporters VGLUT1 and VGLUT2 in neurochemically defined axonal populations in the rat spinal cord with emphasis on the dorsal horn. Eur J Neurosci 17:13-27.

Torres M, Gómez-Pardo E, Dressler GR, Gruss P (1995) Pax-2 controls multiple steps of urogenital development. Development 121:4057-4065.

Vincent JP, Mazella J, Kitabgi P (1999) Neurotensin and neurotensin receptors. Trends Pharmacol Sci 20:302-309.

Wank SA (1995) Cholecystokinin receptors. Am J Physiol 269:G628-G646.

Xu Y, Lopes C, Qian Y, Liu Y, Cheng L, Goulding M, Turner EE, Lima D, Ma Q (2008) Tlx 1 and Tlx3 coordinate specification of dorsal horn painmodulatory peptidergic neurons. J Neurosci 28:4037-4046.

Yasaka T, Tiong SY, Hughes DI, Riddell JS, Todd AJ (2010) Populations of inhibitory and excitatory interneurons in lamina II of the adult rat spinal dorsal horn revealed by a combined electrophysiological and anatomical approach. Pain 151:475-488.

Yoshimura M, Jessell T (1990) Amino acid-mediated EPSPs at primary afferent synapses with substantia gelatinosa neurones in the rat spinal cord. J Physiol 430:315-335.

Zhang X, Tong YG, Bao L, Hökfelt T (1999) The neuropeptide Y Y1 receptor is a somatic receptor on dorsal root ganglion neurons and a postsynaptic receptor on somatostatin dorsal horn neurons. Eur J Neurosci 11:22112225. 